\title{
The species of Scaevola (Goodeniaceae) in Tasmania
}

\author{
Andrew C. Rozefelds
}

\begin{abstract}
Rozefelds, A.C. (Tasmanian Herbarium, GPO Box 252-04, Hobart, Tasmania, 7001 Australia) 2001 The species of Scaevola (Goodeniaceae) in Tasmania. Telopea 9(2): 345-352. At least three species of Scaevola occur in Tasmania. Scaevola albida is extremely rare, and is known from two localities on Flinders Island and also from near Temma on the West Coast of Tasmania, and is restricted to coastal sandy soils. Scaevola aemula is uncommon in the State being restricted to doleritic soils in eastern Tasmania, and appears to have a disturbance-based ecology, appearing after fire or disturbance. Scaevola hookeri is a widespread, variable taxon in Tasmania, occurring from sub-alpine communities to sea level. Although S. calendulacea has been recorded from Tasmania, no supporting collections are lodged in the Tasmanian Herbarium. A key to the species in Tasmania is included, and recommendations are also provided regarding the appropriate conservation status for S. aemula, S. albida and S. calendulacea under the Tasmanian Threatened Species Protection Act (1995).
\end{abstract}

\section{Introduction}

Scaevola is a genus of c. 100 mainly tropical species, that is predominantly Australian (Carolin 1992a). In Tasmania, the number of species has been somewhat unclear. Curtis (1963) recorded four species; S. hookeri (de Vriese) F.Muell. ex Hook.f., S. aemula R.Br., S. albida (Smith) Druce and S. calendulacea (Andrews) Druce. Carolin (1992a), in Flora of Australia, only listed S. hookeri as occurring in the State, although in the Flora of New South Wales (Carolin 1992b) he also recorded S. albida var. pallida from Tasmania. Buchanan (1999) noted that S. aemula also occurs in Tasmania, and in the absence of any verified collections of $S$. calendulacea and S. albida in the Tasmanian Herbarium concluded that both species had been recorded in error from the State. Recent collections have confirmed the presence of S. albida in Tasmania and provided new information on the ecology of these species

In this paper the morphology, distribution, ecology and conservation status of these species in Tasmania is discussed. Flowers were examined with a scanning electron microscope and the specimens were critical-point dried, and placed onto aluminium stubs with tape. They were then sputter coated with gold and examined with a Philips Electroscan Environmental Scanning Electron Microscope 2020, under high vacuum operated at $10-15 \mathrm{kV}$.

Collections in the National Herbarium of Victoria (MEL) have provided additional information on the ecology of S. aemula, and also the distribution of both S. aemula and S. albida in Tasmania. As this is the precursor treatment to the revised State flora, the descriptions are based primarily upon Tasmanian material. The nomenclature and classification follows Carolin (1992a) unless otherwise stated, and the Tasmanian biogeographical regions are those of Orchard (1988). Notes are included if the mainland Australian material differs from the Tasmanian collections. 


\title{
Scaevola L.
}

Perennial herbs, shrubs and scramblers. Leaves alternate, rarely opposite, entire or dentate, sessile or petiolate, often with axillary hair tufts, entire or irregularly serrated. Flowers strongly zygomorphic, solitary or in few-flowered cymes, with paired bracteoles, in leafy or bracteate spikes. Calyx adnate to ovary, lobes often obscure or absent. Corolla with tube split to the base on the upper side expanding distally into an open fan of five lobes, lobes winged white, blue, mauve, rarely yellow; throat often with hairs, hairs simple and/or multicellular (barbulae). Stamens free. Ovary inferior, 1-2(-4) locular, style simple, stigma surrounded by an indusium, indusium oval to \pm horizontal, usually pubescent. Fruit indehiscent, mesocarp fleshy or \pm dry, endocarp hard, sculptured, containing one or two seeds. Seeds ovoid, wingless.

\section{Key to Tasmanian species}

1. Flowers shortly pedunculate, plant prostrate rooting at nodes, lacking bristles around the distal end of the indusium

1. Flowers sessile, plant procumbent or ascending not rooting at nodes, conspicuous bristles around the distal end of the indusium

2. Leaves > $15 \mathrm{~mm}$ long, margin dentate, flowers lilac or bright blue with yellow throat, conspicuous tuft of hairs on back of indusium

S. aemula

2. Leaves $<15 \mathrm{~mm}$ long, margin basal half entire, upper half occasionally dentate, flowers light blue to white, throat white or yellow, lacking conspicuous tuft, but a few scattered hairs may be present on the back of indusium

S. albida

\section{Section Xerocarpa G. Don Subsection Pogonanthera (G. Don) Carolin}

\author{
Scaevola hookeri (de Vriese) F. Muell. ex Hook.f. (Fig. 1)
}

Merkusia hookeri Vriese, Ned. Kruidk. Arch. 2: 159 (1851). Type: Hampshire Hills, Tas., Feb. 1837, R.C.Gunn 848, lectotype K, fide Carolin (1992a: 333); isolectotype HO6975!

Herb prostrate, mat forming, stoloniferous, stems to c. $15 \mathrm{~cm}$ long, rooting at nodes. Stem sparingly hispid with spreading simple hairs. Leaves sessile, ovate to oblong, 8-11(-25) mm long, 3-7(-8.5) mm wide, apex usually obtuse, margins entire or dentate with the proximal margin usually more strongly toothed, both surfaces sparsely appressed-pubescent to almost glabrous. Flowers solitary in leaf axils, on short stalk, 2-10 $\mathrm{mm}$ long, with a pair of elliptical to oblong bracteoles, 3-5 $\mathrm{mm}$ long. Sepal lobes absent or minute. Corolla 5-8 mm long, hispid outside, elliptical, 3-4 mm long, white to pale pink, throat, yellow-white, sparsely pubescent inside. Stamens 5, anther oblong, glabrous, c. $0.7 \mathrm{~mm}$ long. Ovary glabrous or sparingly hirsute, c. $1.0 \mathrm{~mm}$ long, style $3-4 \mathrm{~mm}$ long, indusium c. $1.4 \mathrm{~mm}$ wide, with a few bristles on the back and on the style and lacking conspicuous bristles around the elliptical orifice. Fruit oval in outline, 3.3-3.5 mm long, rugose, distally pubescent, white.

Selected specimens examined: Tasmania: North East: George Town, $41^{\circ} 06^{\prime} \mathrm{S} 146^{\circ} 50^{\prime} \mathrm{E}$, R.C. Gunn s.n., 10 Jan 1843 (HO6976); Blue Tier, A. Simson s.n., 1878 (HO6960). Midlands: Harford, heathy lands, 41 ${ }^{\circ} 15^{\prime}$ S $146^{\circ} 33^{\prime} \mathrm{E}$, H.J. Hamilton 18, 1 Feb 1932 (HO6978). East Coast: Friendly Beaches Road, $42^{\circ} 00^{\prime S} 148^{\circ} 15^{\prime} \mathrm{E}$, altitude $10 \mathrm{~m}$, A. Moscal 6155, $10 \mathrm{Feb}$ 1984, (HO400485); Bellerive, L. Rodway s.n., Jan 1892, (HO6977); Bellerive, L. Rodway s.n., 22 Feb 1913 (HO6980); Flagstaff Marsh, R. Schahinger s.n., 24 Jan 2001 (HO). Furneaux: Lime Pit Road, N of Lady Barron, Flinders Island, 40¹'S 148 ${ }^{\circ} 14^{\prime} \mathrm{E}$, coastal heath, altitude $10 \mathrm{~m}$, Rozefelds 735, 11 Dec 1997, (HO324535). North West: Rocky Cape, R.C.Gunn s.n., 1 Mar 1837 (HO6973). Ben Lomond: Mt Barrow near road, altitude $1100 \mathrm{~m}$,

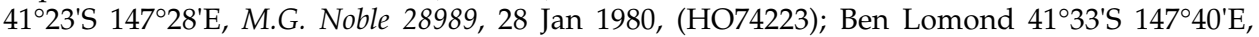




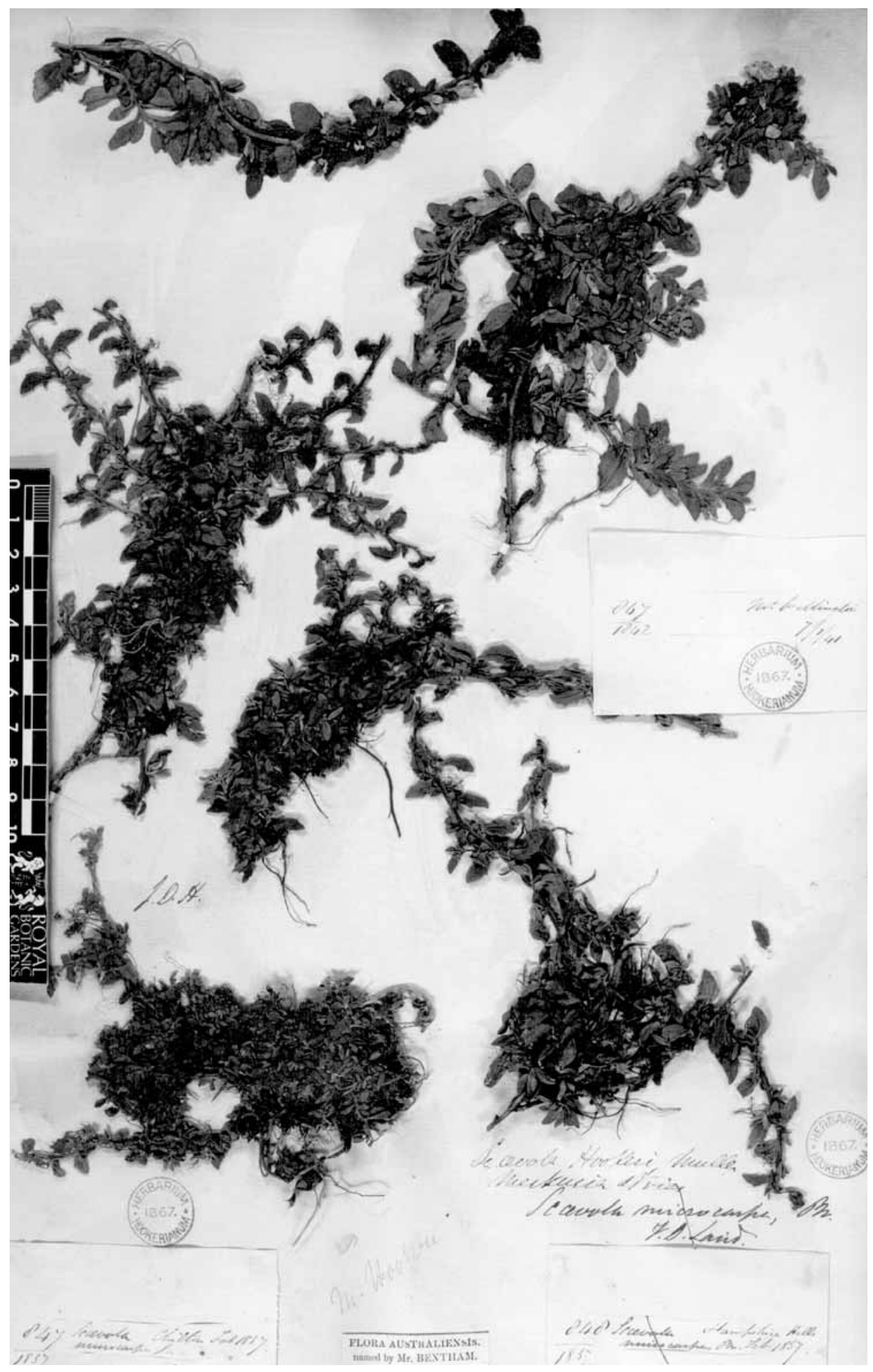

Fig. 1. Lectotype of Scaevola hookeri (de Vriese) F. Muell. ex Hook. f. (Gunn 848, K). The lectotype is the bottom right hand specimen. 
J.B. Kirkpatrick s.n., Jan 1979 (HO29551). North West: The Guardians, H.D. Gordon? s.n., 28 Dec 1937 (HO6981). South West: Abbotts Lookout, 4246'S 146³9'E, altitude $1000 \mathrm{~m}$, A. Moscal 10348, 24 Mar

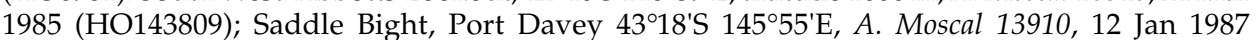

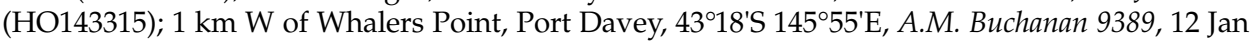
1987 (HO405235); Hartz Mtns, 42²1'S 146²46'E altitude c. 900 m, H.F. Comber 2250, 4 Apr. 1930, (HO6982); Arve Moor, near Hartz Hut, 42 ${ }^{\circ} 4^{\prime}$ 'S 146 ${ }^{\circ} 46^{\prime}$ E, J. Somerville s.n., 20 Jan 1939 (HO6961).

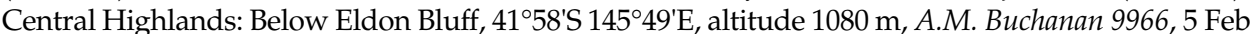
1987 (HO122172); Lake St Clair, 42 ${ }^{\circ} 7^{\prime} \mathrm{S} 146^{\circ} 11^{\prime} \mathrm{E}$, R.C. Gunn s.n., 13 Feb 1845 (HO6972). Mount Field: Near Lake Dobson, 4241'S 146³5'E, altitude 1030 m, J.M.B. Smith 256, 6 Jan 1978 (HO36372); Level of Lake Fenton Huts, W.M. Curtis s.n., 18 Jan 1959 (HO6965); Mount Field, 42 $41^{\circ}$ 'S 146 $53^{\prime}$ 'E, altitude 3400 feet (c. 1000 m), L. Rodway s.n., Feb 1926 (HO6962); Golden Stairs, above Lake Dobson, $42^{\circ} 41^{\prime} \mathrm{S} 146^{\circ} 35^{\prime} \mathrm{E}$, altitude c. 1100 m, J.M.B. Smith 293, 6 Jan 1978 (HO36424). Mount Wellington: The Bend at c. 3700 feet [1000 m], W.M. Curtis s.n., 7 Feb 1947 (HO53397); Mt Wellington, 42 54'S 147¹4'E, J. Milligan s.n., Mar 1849 (HO6979);

Remarks: The species is morphologically variable in regard to leaf size and shape, the degree in which the leaves are serrated, and the hairiness of the leaves, with montane populations often sparingly hirsute and the coastal forms usually more conspicuously hirsute. The indusium and style is conspicuously hairy (Fig. 2A).

Distribution and Ecology: Scaevola hookeri occurs from sub-alpine communities down to sea level in Tasmania (Fig. 3B); and also in Victoria and New South Wales (Carolin 1992a).

Flowering: December-April.

Conservation: common and widespread.

\section{Subsection Biloculatae K. Krause Series Pogogynae Benth.}

Scaevola aemula R. Br.

Lobelia aemula (R.Br.) Kuntze, Revis. Gen. Pl. 2: 378 (1891). Type: Bay X, South Coast, [Port Lincoln, S. Australia] R.Brown, Mar 1802, lectotype BM; isolectotypes K, MEL, fide Carolin (1992a:127)

Herb ascending to decumbent, to $60 \mathrm{~cm}$ tall, stems with coarse antrorse strigose hairs. Leaves tapering towards base, obovate, 15-35 mm long, 8-13 mm wide, apex usually obtuse, margin dentate, antrorse strigose hairs scattered on upper surface, and mainly on main vein and margins on lower surface. Flowers solitary in leaf axils, sessile, with
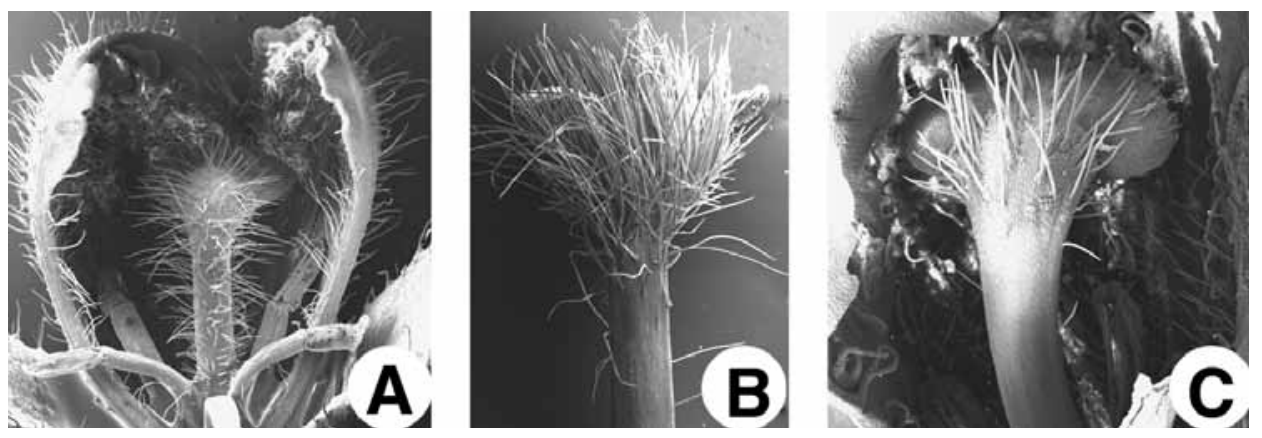

Fig. 2. Indusia of the three species. A, S. hookeri (Schahinger s.n.), partial flower, note hairs on style, and five stamen filaments $\times 8$. B, S. aemula (Rozefelds 1671), indusium dissected from flower, note prominent bristles extend beyond the distal margin of the indusium $\times 10$. C, S. albida (Schahinger s.n., HO510838), note few short, scattered hairs $\times 10$. 

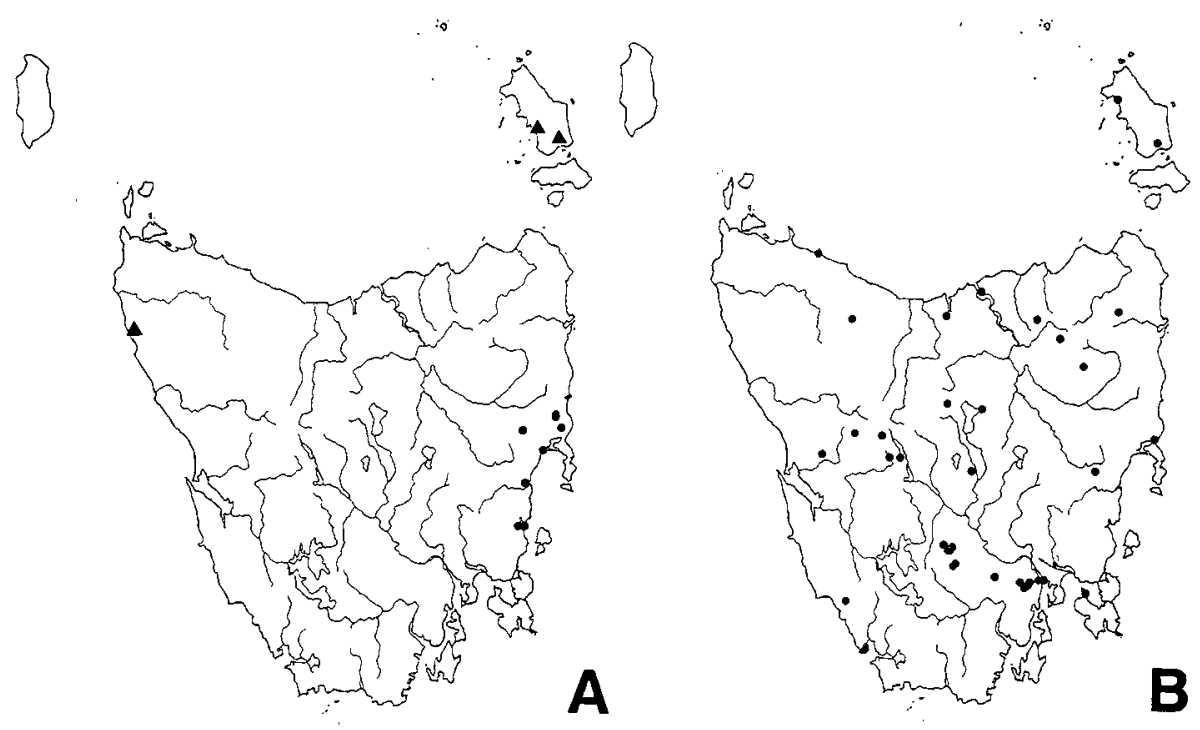

Fig. 3. A, Distribution map of Scaevola aemula (circles) and S. albida (triangles) based upon Tasmanian Herbarium (HO) and National Herbarium of Victoria (MEL) records. B, Distribution map of Scaevola hookeri based upon Tasmanian Herbarium (HO) records.
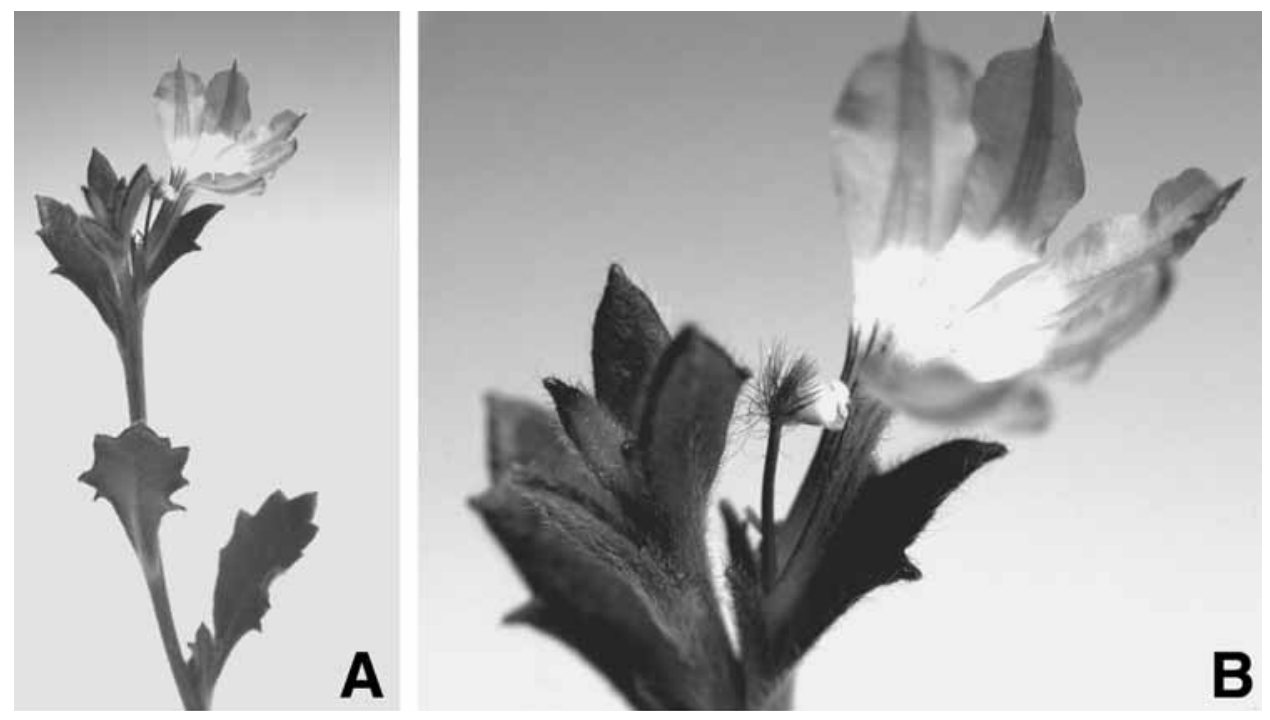

Fig. 4. Scaevola aemula A, Flowering shoot, $\times 0.9$. B, Detail of flower, note the tuft of hairs on the back of the indusium. $x$ 3. (Rozefelds 1671, HO503400) 
a pair of bracteoles, narrowly oblanceolate, almost linear in dried specimens, 5-6 mm long, with conspicuous antrorse hairs along margins and on both surfaces, flowers usually restricted to the ends of leafy and bracteate spikes up to c. $45 \mathrm{~cm}$ long. Sepal lobes, triangular, c. $0.5 \mathrm{~mm}$ long, with antrorse hairs. Corolla 16-20 mm long, with appressed hairs outside, narrowly oblong, 8-12 mm long, purple (when fresh) often blue or white when dried, with a few barbulae near the basal margins of the lobes, throat yellow or white, sparsely pubescent inside. Stamens 5 , anther oblong, glabrous, c. $1.0 \mathrm{~mm}$ long. Ovary pubescent or sparingly hirsute, 2-3 mm long, 2-locular, style 8-9 $\mathrm{mm}$ long, indusium c. $1.5 \mathrm{~mm}$ wide with a posterior tuft of long mauve-brown bristles, and white bristles around elliptical orifice. Fruits not seen. (Fig. 4)

Selected specimens examined: Tasmania: East Coast: On Top of Tiers, Swansea, Storey s.n. (MEL1520774); Swanport, Storey s.n. (MEL1520757); Prosser River, 42³3'S 14752'E, F. Hood s.n., Mar 1979 (HO29298); Apsley River, 4153'S 148¹1'E, P. Collier s.n., 2 Nov 1985 (HO116784); On or near convict road between Prosser Dam and Triabunna, 42 ${ }^{\circ} 33^{\prime} \mathrm{S} 147^{\circ} 55^{\prime} \mathrm{E}$, D. Gregson s.n., 5 Mar 1979 (HO29234); Swanport, 42 05'S 14805'E, L. Rodway 480, Dec 1892 (HO6957); Douglas Apsley

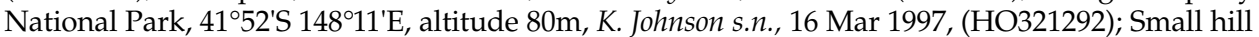
SW of Cusicks Hill, 41 ${ }^{\circ} 57^{\prime} 46^{\prime \prime}$ S $148^{\circ} 14^{\prime} 26^{\prime \prime E}$, altitude 100m, area previously burnt by fire, Rozefelds 1671, 5 Apr 2000 (HO503400). Victoria: Mallee sandhills W of Lake Albacutya, 3544'S $141^{\circ}{ }^{\circ} 5^{\prime} \mathrm{E}$, area burnt by wildfire in Dec 1977, A. Morton s.n., 17 Nov 1979 (MEL562061); $6 \mathrm{mls}$ [= $9.6 \mathrm{~km}] \mathrm{W}$ of Annuello, burnt three or four years ago, N. MacFarlane s.n., 8 Feb 1971 (MEL1520822).

Remarks: The species has a prominent tuft of hairs on the top surface of the indusium. No fruiting material has been collected from Tasmanian plants. Jeanes (1999) recorded that the fruits in mainland material are ovoid, 3-4 mm long, rugose and pubescent.

Distribution and Ecology: Rozefelds 1671 records the species growing in a Eucalyptus amygdalina community on dolerite. Scaevola aemula in Tasmania is restricted to the Great Oyster Bay region which was recognised by Kirkpatrick \& Brown (1984a, b) as a centre of higher-plant endemicity in Tasmania (Fig 2A). The Tasmanian populations of S. aemula, along with Eucalyptus barberi, Ozothamnus lycopodioides, Lasiopetalum micrantheum and Melaleuca pustulata are restricted to doleritic soils in this region. Scaevola aemula is also known from South Australia, Victoria and New South Wales (Carolin 1992a).

Flowering: recorded in flower in November and December, and March and April.

Conservation Status: The species is currently listed as 'endangered' in the Tasmanian Threatened Species Protection Act (1995). Scaevola aemula in both Tasmania and Victoria appears to have a disturbance-based ecology and is recorded as appearing after fire or disturbance due to land clearing. Some specimens show evidence of having been grazed, although it is unknown whether this is by native marsupials or introduced mammals. It is also unknown whether this grazing pressure could be impacting negatively on the species.

\section{Scaevola albida (Smith) Druce}

Goodenia albida Smith, Trans. Linn. Soc. London, Bot 2: 348 (1794). Type: Port Jackson, N.S.W., J. White, holotype Linn-SM, fide Carolin (1992a: 122).

Prostrate to ascending herb to $20 \mathrm{~cm}$ high, forming irregular clumps, stems with antrorse strigose hairs. Leaves shortly petiolate to sessile, obovate to elliptical, 7-14 mm long and 2.2-5.0 mm wide, apex acute, margin of basal half of leaf entire, upper half occasionally dentate, a few to scattered antrorse strigose hairs on upper surface, and on leaf margins and main vein on undersurface. Flowers solitary in leaf axils, sessile, with a pair of narrow oblanceolate bracteoles, 9-10 $\mathrm{mm}$ long, with a few antrorse hairs along margins, flowers usually restricted to the ends of leafy and bracteate spikes up to c. $7 \mathrm{~cm}$ long. Sepal lobes deltoid, c. $0.6 \mathrm{~mm}$ long, margin sparsely ciliate. Corolla $8-12 \mathrm{~mm}$ 
long, with appressed hairs outside, narrowly elliptical to oblong, 5-6 mm long, blue or white, throat white or yellow, sparsely pubescent inside. Stamens 5, anther oblong, glabrous, c. $1 \mathrm{~mm}$ long. Ovary glabrous, c. $1.5 \mathrm{~mm}$ long, 1-locular, single ovule, style 3-5 mm long, indusium c. $2 \mathrm{~mm}$ wide, glabrous on the back or with a few scattered hairs and short white bristles occur around the triangular orifice. Fruits ellipsoid, glabrous with rugose mesocarp, $2.5 \mathrm{~mm}$ long, c. $1.5 \mathrm{~mm}$ wide.

Selected specimens examined: Tasmania: Furneaux Group: Lime Pit Road, N. of Lady Barron, Flinders Island, 40'11'S 148 $15^{\prime} \mathrm{E}$, Rozefelds 736 and S. Harris, 11 Dec 1997 (HO324559); and L. Gilfedder s.n. (HO); Blue Rocks District, Flinders Island, J.S. Whinray 2128, 10 Nov 1970 (MEL576015); Flinders Island (MEL1520889); Tasmania (no specific locality) (HO53395); Inland from Hazard Bay, near Temma, upper slopes and crest of stabilised sand dune, very low open heath with ground covered by short Poa rodwayi, $41^{\circ} 15^{\prime} \mathrm{S} 144^{\circ} 42^{\prime}$ E altitude 20m, R. Schahinger s.n., 22 Nov 2000 (HO510838) and R. Schahinger s.n., 10 Jan 2001 (HO510839). Victoria: Point Lonsdale, K. Cowle (MEL579650);

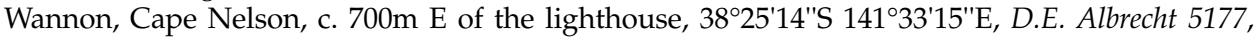
3 Dec 1992 (MEL2017295).

Remarks: The material of S. albida collected from Tasmania, with its small leaves which are less $20 \mathrm{~mm}$ long and white to light blue flowers is probably referable to var. pallida (R.Br.) Carolin. Cooke and Carolin (1986) recorded that the back of the style was glabrous in var. pallida, although in the Tasmanian collections it is glabrous or has a few scattered hairs (Fig. 2C). In mainland Australia the species is heteromorphic and Jeanes (1999) considered that as intermediates between the type variety and var. pallida occurred there was little point in recognising varieties. Carolin (1992b) recorded the species from Tasmania, but no additional collections were found in NSW (J. Everett pers. comm. 2001).

Distribution and Ecology: Scaevola albida was collected from heath communities, and is known from two localities on Flinders Island (Furneaux Group), of which at least one is on Quaternary sediments, and it was recently found near Temma on calcareous sands on the West Coast of Tasmania (Fig. 3A). The Temma population consists of over 200 plants (R. Schahinger pers. comm., 9 Feb 2001). It also occurs in Victoria, New South Wales, Queensland and South Australia (Carolin 1992a).

Flowering: November-January.

Conservation: It is currently listed as 'rare' in the Tasmanian Threatened Species Protection Act (1995). As the species is currently known from only three localities, a higher conservation status, such as, 'endangered' is appropriate. Further fieldwork in the Furneaux Group and the West Coast of Tasmania is needed to ascertain the distribution and hence the rarity of this species.

\section{Conclusions}

Three Scaevola species are recorded from Tasmania. Scaevola hookeri is common, while both $S$. albida and $S$. aemula are poorly represented in herbarium collections and are considered to be threatened in the State. Scaevola calendulacea has not been verifiably recorded from the State, although as it occurs along the coast in Victoria it could be expected to be found on some of the Bass Strait Islands. In Victoria, it is recorded from coastal sand dunes and can be distinguished from other Tasmanian species by its fleshy fruits and more or less entire, thick-textured leaves (Jeanes 1999). Extensive collecting from the Bass Strait Islands, by Tasmanian Parks and Wildlife staff, however, has not yielded any collections. As there are no collections of this species known from Tasmania (Buchanan 1999), it is appropriate to delete this species from the list of 'rare' species in the Threatened Species Protection Act (1995) for the State. 


\section{Acknowledgments}

Material collected for this study was obtained during fieldwork in 1997 with Stephen Harris (Tasmanian Parks and Wildlife Service). This research was supported by funding from the Australian Biological Resources Study towards the Flora of Tasmania Project. The Australian Botanical Liaison Officer, Prof Rod Seppelt (2000-2001) provided Cibachromes of type material in K, and extracts from papers unavailable in Tasmania. Simon Cuthbert (Tasmanian Museum and Art Gallery) took the photos used in Fig 4. Alex Buchanan and Richard Schahinger provided comments on the manuscript.

\section{References}

Buchanan, A.M. (1999) The Census of the Vascular plants of Tasmania. Tasmanian Herbarium Occasional Publication No. 6.

Cooke, D.A. \& Carolin, R.C. (1986) Scaevola in Flora of South Australia, Part 3, edn 4, edited by J.P. Jessop \& H.R. Toelken (South Australian Govt Printing Division: Adelaide).

Carolin, R.C. (1990) Nomenclatural notes, new taxa and the systematic arrangement in the genus Scaevola (Goodeniaceae) including synonyms. Telopea 3(4): 477-515.

Carolin, R.C. (1992a) Scaevola in Flora of Australia 35: 84-146.

Carolin, R.C. (1992b) Goodeniaceae in Flora of New South Wales, Vol 3 (New South Wales University Press: Kensington)

Curtis, W.M. (1963) The Student's Flora of Tasmania Part 2. (Govt Printer: Tasmania).

Jeanes, J. (1999) Goodeniaceae in Flora of Victoria Vol 4: 589-615 (Inkata Press: Melbourne).

Kirkpatrick, J.B. \& Brown, M.J. (1984a) A numerical analysis of Tasmanian higher plant endemicity. Botanical Journal of the Linnean Society 88: 165-183.

Kirkpatrick, J.B. \& Brown, M.J. (1984b) The palaeobiogeographical significance of local endemism in Tasmanian higher plants. Search 15: 112-113.

Orchard, A.E. (1988) A natural regions map for Tasmania. Papers and Proceedings of the Royal Society of Tasmania 122: 47-51.

Threatened Species Protection Act (1995) (Govt Printer: Tasmania).

Manuscript received 29 September 2000

Manuscript accepted 15 March 2001 